\title{
STUDY OF CHILDHOOD CULTURE AMONG THE SIBERIAN INDIGENOUS PEOPLES (ON THE FIELD RESEARCH MATERIAL OF THE CHULYM ETHNOCULTURAL GROUP IN THE TYUKHTET DISTRICT OF THE KRASNOYARSK TERRITORY)
}

\author{
Prof. Dr. Natalia P. Koptseva ${ }^{1}$ \\ Prof. Dr. Vladimir I. Kirko ${ }^{1,2}$ \\ ${ }^{1}$ Siberian Federal University \\ ${ }^{2}$ Krasnoyrsk State Pedagogical University named after Victor Astafievs
}

\begin{abstract}
We analyzed the results of field studies in the Tyukhtet District of the Krasnoyarsk Territory. The subject of the study is the childhood culture of the indigenous, scarce peoples of the Krasnoyarsk Territory. A group of researchers from Siberian Federal University had studied the Chulym ethnocultural group ("chulymtsy"). The target of the study was Chulym children. The main research methods were field studies and focus groups, which involved observation and expert interviews. The general culture of childhood, their spheres of leisure time, healthcare, and education were taken into account. Currently, the culture of indigenous small-numbered peoples of the Krasnoyarsk Territory is actively influenced by other civilization standards and values. Preservation and development of the unique culture of the indigenous small-numbered peoples of the Krasnoyarsk Territory depends on the childhood culture of the indigenous peoples. Childhood cultural practices in the Chulym ethnocultural group are destroying the ethnocultural identity of the indigenous peoples. It is necessary to change the state's cultural policy. The childhood culture of the indigenous scarce peoples of the Krasnoyarsk Territory should be protected by the state and public organizations.
\end{abstract}

Keywords: Siberian Arctic, indigenous peoples, religion, tradition

\section{INTRODUCTION}

The history of the study of religion indigenous peoples Siberian Arctic has more than a century. These studies have several areas: statistical studies, socio-economic, cultural and ethnographic research. The study of ethnogenesis of indigenous ethnic groups Siberian Arctic also solves the problem of the interaction of socio-cultural practices of different ethnic groups and the common origin of their cultural heritage. In the history of the study of indigenous peoples Siberian Arctic stages can be distinguished: studies to the XIX century; study of end XIX - XX century; modern period Indigenous Studies (1990 - 2000s) [1], [2], [3], [4].

Prolonged relevance and consistency of research interest in the environment of indigenous ethnic groups explained primarily, by the fact that socio-cultural practices of these territories are found in their extreme contrast to the way of life of other nations, and to the present day in some measure preserve this specific aspect. As a result of the 
research activity is now possible to observe the addition of two polar points of view in relation to the cultural heritage of indigenous peoples, manifested as the basic contradiction of modern science on this issue, and the dispute of cultural realities [5], [6], [7], [8]. This contradiction can be formulated as recognition of the need to preserve the cultural heritage of indigenous peoples and at the same time the unacceptability of inhibition processes of modernization of the changing ethnic group.

The most consistently developing and sustainable is a look at the cultural heritage of indigenous ethnic groups in the Siberian Arctic as a unique and tragically lost. This approach asserts the need to preserve and protection of cultural heritage of indigenous peoples, especially in a situation of small number. Thanks to this approach were formed vast ethnographic collections of leading Russian and regional museum center. Ways of preserving cultural heritage, recognized in the context of this position are different the locking mechanisms and restoration of the traditions of indigenous peoples: actively used by method of museumification of cultural heritage in its various aspects (museum collections and exhibitions), the method of preservation of intangible cultural heritage (folklore, language), and technology of restoration of heritage (preparation of dictionaries, writing, implementation of training) [9], [10], [11, [12].

Alternative viewpoint argues that conservation measures should not provoke "museumification of people" and interfere with indigenous ethnic groups to follow the path they need change. Modern Russian society is inherent to romanticize the culture, so that indigenous peoples are no longer to be identified in their modern everyday life and mythology of the past becomes a model of the desired social organization. On the one hand, the romanticizing of the past of these peoples understood as a cultural nostalgia, on the other hand, indicates of nationalistic sentiments as "outside" and "inside". Processes of romanticization of culture undeservedly deprived of attention researchers because they are the current trends and view are closely related to problems of nationalism, cultural distance, identity and lead to misunderstanding of contemporary social trends, stating the need to preserve traditional culture media, ignoring the view of the representatives of indigenous peoples as man in his changing every day. Such conceptual stance characterizes of post-Soviet Russia in ethnology. Canadian anthropologist J.D. Anderson noted the enormous gap between prevalent image of the indigenous peoples represented in the classical studies and real their representatives have long to opt for a orientation in the future, not the past, and included in the contemporary socio-cultural processes [13].

Nevertheless, even in conditions of progressive changes worldwide phenomenon largely indicate high adaptive capacity of ethnic traditions. This study has a purpose to solve the contradictions prevalent in academic discussion of views on the cultural heritage of the indigenous peoples of the Siberian Arctic using the search capabilities of preserving the cultural heritage of the indigenous population in modern conditions. Orientation of this search - avoid the tendency "conservation" lifestyle of indigenous peoples to the existing socio-cultural level and create conditions for the implementation of aspects of cultural heritage of their actual the function of maintaining ethnic identity [14].

\section{MATERIALS AND METHODS}


In 2010-2016, researchers and graduate students of Siberian Federal University, Krasnoyarsk State Pedagogical University, Krasnoyarsk State Medical University, and Krasnoyarsk State Agricultural University carried out field research in the settlements predominantly populated by indigenous peoples of the Siberian Arctic: Evenks Dolgans, Selkups, Nenets, Yakuts [15]. Field studies conducted in the following towns: settlement Surinda (Evenkia), village Essey (Evenkia), village Karaul (Taimyr), village Nosok (Taimyr), village Pasechnoe (Tyuhtet) settlement Hordogoy (Yakutia), village Hatanga (Taimyr), village Farkovo (Turukhansk). The village Surinda (Evenkia) is a place of residence Evenks are engaged in nomadic reindeer herding. The village Nosok and the village Karaul there are places where they live Nenets. Nenets engaged in nomadic reindeer herding and fishing. Essey settlement is a place where the Yakuts live in isolation. They are engaged in hunting, fishing, gathering berries and useful plants. The village Hatanga (Taimyr) - this is the place where they live Dolgans. They hunt wild reindeer, fishing. The village Hordogoy (Yakutia) - this is the place where they live Yakuts. They occupy a traditional Yakut horse breeding breed, hunting, fishing, gathering medicinal plants. The village Pasechnoe is a place where indigenous ethnic group "Chulyms" live. They are engaged in fishing. Basically, their employment is associated with modern and not traditional professions. Selkups live in the village Farkovo. In Farkovo field studies were conducted in 2010.

During field studies used these methods: in-depth interviews, photo and video shooting, questionnaires, participant observation, focus groups, interviews with experts. The scientists kept diaries of observations, where every day recorded the results of their research, did the primary analysis. To obtain the results were studied field research of other scientists; the results were compared and corrected. Also used by statistical information. Been analyzed the research of shamanism in the last 100 years.

The results of field studies were discussed at an expert workshop in the Siberian Federal University, Krasnoyarsk State Pedagogical University in 2010-2016.

\section{RESULTS}

Religion is the quintessence of the ethnic group. On signs, symbols and rituals of religion based processes of ethnic self-identification. The core of every ethnic and cultural group makes up etalons of economic and religious life that are typical of this ethnic group. Shamanism is an ancient religion of the indigenous peoples of the Siberian Arctic. Despite the active Christianization of the population of Siberia and the North since the 17th century (in the case of certain territories - from the 19th century), ethnographers in the late 19th - early 20th century fixed the widespread dissemination and use of religious practices of shamanism in northern and Siberian indigenous peoples. Currently there shamanism in different nations of the world, researchers are paying particular attention to issues of social essence of shamanism - shaman personality function in society, and the generally accepted definition of shamanism in indigenous studies do not exist.

1) Shamanism is the religion of the indigenous peoples of Siberia and the North; shamanism has the earliest form of religion. In this case, shamanism is seen as the result of a common religious experience in the Arctic, Siberian and Asian peoples, and not as a creation of shamans as the holder of a special ecstatic experience. In this case, 
shamanism as a religion of the people often combines elements of non-shamanic, shamanic origin and elements borrowed from other religions.

2) The shamanic complex - a special, harmonious and complex system of philosophy, which regulates ways of life of the people. The basis of this system supposed to definite view of the world, which includes: the structure of the world (The Upper and The Lower worlds of spirits, average human world), the relationship of its elements (the existence of a world axis - the World Tree), the mediator in the human world - the shaman (who is able to have contact with the worlds of spirits, the ability to use for the benefit of the community), which serves as a link between the members of their social group (family, settlement), and supernatural powers. Special ritual practice of shamanism in this complex acts "kamlanie" - action by shaman conducive to immersion in an altered state of consciousness and his journey to the spirit worlds. Songs and music ritual has certain laws and the function of ceremonial musical universal language of communication with the supernatural world. The rites of shamanism among the indigenous peoples of Siberia and the North in the first half of the 20th century were identical to the most important rites of the Eneolithic. Possible to see the relationship of modern rituals of shamanism in Siberia and the Far North with the worldview of the ancient population of Siberia, especially the content of which is the knowledge of complex rites and rituals of initiation to extraterrestrial space - The Upper and The Lower worlds.

3) Shamanism is the ordinary worldview, the special status which was created as a result of the dominant colonial approach with regard to the indigenous peoples of the North. This view is inherent to researchers of culture and history of the North postSoviet period, which has allowed rethinking features of the relationship between the dominant and the small indigenous peoples of Russia. Shamanism as a scientific concept created at the initial stage of the Russian colonial project when the symbolic boundary, separating the European part of Russia from the conquered Siberia just started installed. Shamanism in this context does not exist as a distinct religious institution, but it was designed the process of becoming of the Russian Empire in the texts of scientists. The concept of shamanism played a significant role in the establishment of the colonial order because observed phenomena of life shamans in the process of discussion of the established and confirmed the social inequality of the peoples living in the West and in the East of the Russian Empire. The result of this was the creation of an artificial opposition of "East - West". This view is based on the study of colonial discourses in relation to indigenous peoples of Siberia and the North.

4) Shamanism is a mechanism of social regulation. This view of shamanism fixes as the main aspects of social function of the shaman. Shamanism as a system is understood as a universal self-adjusting mechanism of collective mental regulation, effective way to protect and manifestations of the biological functions of the genus.

5) Shamanism as a mental abnormality - this view is an accepted in the 19th - early 20th century. In ethnographic studies shamanism is regarded as a special form of polar hysteria, which is endemic, or method of subordination of on the part of shamans.

6) Shamanism as ecstatic techniques of consciousness expansion (communication with other worlds, returning to a state of chaos as preparation of a new act of creation). This aspect of the study of the phenomenon of "shamanism" is especially popular today. These aspects of shamanism are very interested for specialists in the study of altered 
states of consciousness, what is called an ecstatic state of the shaman during the ritual, and specialists practicing similar technology. For example, shamanism understands founders and followers of Transpersonal Psychology, and the creators of the "combined" method of personal shamanism, that involve shamanic ritual practices in the context of other philosophical and psychological systems. In this case study examines how shamanic techniques to facilitate the elimination of unwanted internal states and external circumstances, ritual practices of shamanism adaptation to the conditions of modern life, the analysis what elements shamanic traditions, and how can help a person in his modern life. In Transpersonal Psychology true shaman is a person able to subdue the altered states of consciousness to continue to use them for the benefit of society; basis of shamanic practices - controlled act of mental dissociation ", which realized through both the external ritual reenactment of the internal events; with the shamanic experience and presentation are evaluated as having the archetypal and therefore objective. Practically oriented provisions of Transpersonal Psychology pose a newly developed ways of overcoming of fears and emotional crises by awakening man in an "internal of the shaman" - "the dreambody".

7) One of the most relevant topics of ethnography today - the current state of shamanism and ways to adaptation in the modern world. In the past 10 years, researchers of shamanism - ethnographers, anthropologists, sociologists, - actively discussing on the relevance of shamanism for the indigenous peoples of Siberia and the Far North. This revival of shamanism or a "historical reconstruction"?

Start the recovery of shamanism - the period of the 1990s, the period of active ethnic identity and identity for indigenous peoples of the Siberian Arctic. Shamanism has three determinants: 1) mythological determinant - view of the world and the relationship of its parts; 2) the determinant of the medium - the presence of a mediator that connects different parts of the world; 3) the determinant of ritual - an implementer of this connection. Structure of society in the worldview of shamanism - a pyramid, where the first level is a broad mass (the uninitiated, the profane), the second level - is limited in the number of society of shamanism (intermingled), and the upper level - the minimum number of community by shamans (dedicated). Shamanism as a religious practice has always existed in these three plans: 1) in the activities of shamans professionals elected; 2) in family ritual and medical practice in the family or clan, together with elementary religious and magical practices; 3) in the worldview of society, have established themselves as complex of ideas and beliefs on the basis of the sacred knowledge of shamans and transformation of knowledge among the uninitiated.

During the Soviet period shamanism significantly was transformed as a result of the atheistic policy of the state (the destruction and isolation of professional shamans upbringing work among the masses, prohibitions on traditional medical practices, policies to ban the traditional part of the national culture, which is associated with the religious and magical knowledge). Therefore, in the Soviet period, in varying degrees, to modify all three spheres of existence shamanic practices, each of them is now recovering on its own. By the end of the 20th century professional sphere of shamanism practically ceased to exist because of small number (lack) dedicated to the shamans. Domestic shamanism remains in rural areas and to a large extent preserved in the cities. Shamanism gradually ceased being a common outlook: several generations of people who grew up in boarding schools, in isolation from the clan traditions, ceased to be the 
bearers of these traditions. In this shamanic representation preserved in the forms of superstition.

During the period of the ban on shamanism among the indigenous population of Siberia and the North begins to spread phenomenon called researchers "Shamans without drums" - gradually formed and separated group of people who were not able to enter in shamanic practices, including due to the lack of teachers, but in their characteristics were designed to therefore have a "shamanic gift." In the future, this group of people influenced the change shamanic tradition "from within". They have influenced the modern shamanism, especially with increasing demand for shamanic knowledge and address to the "shaman without a drum" as teachers and consultants from the modern shamans. As a result, a process accompanied by the life of indigenous peoples in the Soviet era, shamanism significantly was transformed, and the number of practitioners dedicated to the shamans comes to a critical point of extinction.

The main features of the religion of indigenous peoples of the Siberian Arctic:

1) The combination of ritual objects - for example, in the ethnic museum on Lake Lama remained bed - image assistant of the shaman and embodiment of the spirit made from icons.

2) The combination of a doubling or ritual practices - conducting repeated rituals; especially with regard to the rites of purification / sanctification and remembrance (shamanic rituals are performed along with the church, Christian).

At the same time, because of remoteness Territory of Distribution of shamanism from the center of the state and discontinuous, distance from each other settlements in the Far North shamanic practices in some regions are preserved in the original version.

\section{CONCLUSIONS}

Currently, the Siberian Arctic regions among indigenous peoples there are the following kinds of shamanism.

1) Shamanism as a result of the evolution of the initial regional traditions. In some regions of the Siberian Arctic, where previously practiced hereditary shamans, the tradition was weakening, but not completely interrupted. There remained traditional practices, as well as among the older and middle generations preserve the tradition of shamanism household. In regions where the tradition was largely interrupted, shamanism has evolved under the influence of individual interpretations using the "shaman without a drum." Is also such regions of the Siberian Arctic, where shamanism survived in a latent form - was its recovery. Are here prepared successors of shamans have practiced in secret, and after removal of the ban on shamanic practices they have shown high activity.

2) Neoshamanizm was formed in a situation of significant interruption in tradition and its deformation and the presence of a wide array of educational opportunities to various medical, hypnotic, magical techniques. Many candidates for the shamans were trained in various training courses that allowed them master the traditional shamanism unusual techniques or learn shamanic techniques in a non-traditional version (teachers could serve "without shaman drums"). Characterized with forming of professional society's 
shamans, shaman initiation into people of other nationalities, travel to shamanic practices and seminars.

3) Urban Shamanism - practice of shamanism in urban environments. Representatives of this trend are divided into shamans and neoshamans. Urban Shamanism distributed not only in Siberia and the Far North, but also in the central regions of Russia.

4) Eksperientsialny (from "knowing from experience") Shamanism - a variant of shamanic practices, aimed at the widest possible audience, it does not require election and possession of "shamanic gift", and suggests the possibility of the development of any interested technician dive into an altered state of consciousness and management (which is characteristic of shamans). In Russia there is generally in the business form. In the original version of this kind of shamanism was formed as a technique to help solve psychological problems and was sent to control internal world and external circumstances.

Thus, the initial resistance during the Soviet period shamanistic practices and the subsequent surge in the relevance of shamanism in the post-Soviet period has led to various transformations of this tradition. Shamanism in the representation of the indigenous peoples of the Siberian Arctic is a sphere of fixing their ethnic identity almost in the first place. That is why the demand of shamanism has increased dramatically with the collapse of the Soviet Union, when each of the peoples of Russia began to actively seek the means of ethnic identity.

\section{ACKNOWLEDGEMENTS}

The research was carried out within the grant of RGFH and Krasnoyarsk Krai 17-1624004 devoted to the topic: "Development and reproduction of human capital-the basis for improving the quality of life of indigenous small peoples of the North and Arctic regions of the Krasnoyarsk Krai in the conditions of traditional nature use."

\section{REFERENCES}

[1] Pedersen M.A., Complete Title of the paper, Journal of the Royal Anthropological Institute, UK, vol.7/issue 3, pp 411-427, 2001;

[2] Koptseva N., The current economic situation in Taymyr (the Siberian Arctic) and the prospects of indigenous peoples' traditional economy, Ukraine, Economic AnnalsXXI, vol. 9-10, pp 95-97, 2015.

[3] Koptseva N., Kirko V., Modern specificity of legal regulation of cultural development of the indigenous peoples of theArctic Siberia (the Altay Region, the. Zabaikailsky Region, Republic of Buryatia, Russia), Life Sciences Journal, USA, vol. 11/issue 9, pp 314-319, 2014.

[4] Kistova A.V., Pimenova N.N., Zamaraeva Ju.S., Reznikova K.V., Modern specificity of legal regulation of cultural development of the indigenous peoples of theArctic Siberia (the Altay Region, the Zabaikailsky Region, Republic of Buryatia, Russia), Life Sciences Journal, USA, vol. 11/issue 6s, pp 593-600, 2014. 
[5] Brightman M., Grotti. V.E., Ulturgasheva O., Animism in rainforest and tundra: personhood, animals, plants and things in contemporary Amazonia and Siberia, UK, Berghahn Books, 2014;

[6] Libakova N.M., Sertakova E.A., The Method of Expert Interview as an Effective Research Procedure of Studying the Indigenous Peoples of the North, Russia, Journal of Siberian Federal University. Humanities \& Social Sciences, vol. 8/issue 1, pp 114-129, 2015 .

[7] Siikala A.L., The Siberian Shaman's technique of ecstasy, Scripta Instituti Donneriani Aboensis, Finland, issue 11, pp 103-121, 2014.

[8] Relic R., Genesis and Origin of the Esoteric Culture in White Shamanism: A Historical-Cultural Analysis, Journal of Human Values, India, vol. 21/issue 2, pp 99$105,2015$.

[9] Betts M.W., Hardenberg M.,, Stirling I., How Animals Create Human History: Relational Ecology and the Dorset-Polar Bear Connection, American Antiquity, USA, vol.80/issue 1, pp 89-112, 2015;

[10] Krivonogov V.P., The Dolgans' Ethnic Identity and Language Processes, Russia, Journal of Siberian Federal University. Humanities \& Social Sciences, vol. 6/issue 6, pp 870-881, 2013.

[11] Peers E.K., The Post-Colonial Ecology of Siberian Shamanic Revivalism, Worldviews: Global Religions, Culture, and Ecology, UK, vol. 19/issue 3, pp 245-264, 2015 .

[12] Libakova N.M.., Sitnikova A.A., Sertakova E.A., Kolesnik M.A., Ilbeykina M.I., Interaction of the Yakut ethnicity and biological systems in the territory of the Sakha Republic (Hordogoy settlement, Suntarsky District) and Krasnoyarsk Krai (Essey settlement, Evenks District), Life Sciences Journal, USA, vol. 11/issue 6s, pp 585-592, 2014.

[13] Anderson D.G., Identity and ecology in Arctic Siberia: the number one reindeer brigade, UK, Oxford University Press, 2000;

[14] Alberts T., Shamanism, Discourse, Modernity, Netherlands, Ashgate Publishing, Ltd., 2015.

[15] Seredkina N.N., Revisiting Methodological Principles of Cultural-Semiotic Approach in Studying Art of Indigenous Peoples of the North, Siberia and the Far East. Journal of Siberian Federal University. Humanities \& Social Sciences, Russia, vol. 7/issue 8 pp 1342-1357, 2014. 